\title{
The influence of plant density and doses of fertilizers on photosynthetic activity and yield of soybean of middle-ripening variety Sviatohor in conditions of irrigation
}

\author{
Vozhegova R. ${ }^{1}$, Borovik V. ${ }^{2}$, Marchenko T. ${ }^{3}$, Rubtsov D. ${ }^{4}$ \\ Institute of Irrigated Farming of NAAS, Naddnipryanske, Kherson, 73483, Ukraine \\ e-mail: ${ }^{1}$ izz. ua@ukr.net, ${ }^{2}$ veraborovik@meta.ua, ${ }^{3}$ tmarchenko74@ukr.ner, ${ }^{4}$ daniilrublev3@gmail.com \\ ORCID: ${ }^{1} 0000-0002-3865-5633,{ }^{2} 0000-0002-6507-4006,{ }^{3} 0000-0001-6994-3443,{ }^{4} 0000-0002-9776-0844$
}

Goal. To establish the optimal parameters of photosynthetic activity of crops of mid-season soybean variety Sviatogor in conditions of irrigation in the South of Ukraine depending on plant density and doses of nitrogen fertilizers. Methods. The field - for determination of yield; calculation - for optimization of doses of mineral fertilizers, plant density; measurement- weighe - for fixation of plant height, leaf area, and photosynthetic indices. Results. The density of sowing significantly influenced the leaf area of soybean plants, its indices varied in the range of $23.5-47.38$ thousand $\mathrm{m}^{2} /$ ha at the density of 300 thousand plants/ha; $26.19-52.42$ thousand $\mathrm{m}^{2} /$ ha at the density of 600 thousand plants/ha; $50.56-49.92$ thousand $\mathrm{m}^{2} / \mathrm{ha}$ at the density of 900 thousand plants/ha. It was fixed that the leaf area of plants in the plots with the introduction of $\mathrm{N}_{30}$ and $\mathrm{N}_{60}$ was $50 \%$ and $49 \%$ more than in the variant without fertilizers. High yield was provided by the density of plants $600 \mathrm{t} / \mathrm{ha}$ on the background of fertilizers $\mathrm{N}_{30}$ and $\mathrm{N}_{60}$. Conclusions. For the first time for the South of Ukraine, features are determined of the formation of the photosynthetic activity of soybean crops of mid-season variety Sviatohor depending on plant density and doses of nitrogen fertilizers, providing the yield at the level of $4.32-4.47$ t/ha. The best performance of interfacial photosynthetic capacity (beginning of flowering - beginning of seed ripening) - 1.38-1.23 million $\mathrm{m} 2$ of days/ha, and over the vegetation period - $3.45-3.19$ million $\mathrm{m}^{2}$ of days/ha were formed in areas where the plant density was 600 thousand plants/ha on the background of $N_{30}$ and $N_{60}$ respectively. Correlation is determined between the yield level and the studied factors. It is found that the maximum leaf area in the ripening phase of the seeds is 52.42 thousand $\mathrm{m}^{2} / \mathrm{ha}$ at a plant density of 600 thousand plants/ha, and the rate application of nitrogen fertilizer involves a dose of $\mathrm{N}_{30}$.

Key words: nutrition background, photosynthetic apparatus, nitrogen fertilizer, leaf area. DOI: https://doi.org/10.31073/agrovisnyk202004-09

Field crops are powerful photosynthetic systems that, by the ability to absorb solar energy, are 2 to 5 times greater than natural land, including forest plantations. Biomass yield is created due to certain conditions as a result of photosynthetic activity and active root system of plants [1]. One of the most dynamic indicators of photosynthetic activity of crops is the leaf surface. It is known that leaf is the main organ of photosynthesis, although this role is also played by green stems, inflorescences at the beginning of their formation, and even roots [2].

Many factors influence the size of the leaf surface and the duration of its life - sowing methods, soil moisture, agrophytocenosis thickening, fertilization, sowing time, soil cultivation [3], variety genotype, environmental conditions of the region, etc. [4]. It is known that the size of the leaf surface of plants, the duration of its operation, are the determining factors of photosynthesis productivity and the size of yield. There is a direct relationship between these values. With the increase in the area of the total area of the leaves, the yield increases, first of all, due to the absorption of more solar radiation. The larger the area of leaf surface is crops, the better they capture solar radiation and the more vigorous is the accumulation of organic matter, except in some cases, which cause an increase in the yield of this crop [5-8].

Soybeans form an assimilation apparatus in a wide range - from 20 to 70 thousand $\mathrm{m}^{2} / \mathrm{ha}$. Optimal this indicator per 1 ha is considered to be $40-50$ thousand $m^{2}[9,10]$. If the area of the leaf surface is smaller, then the opto-biological structure of sowing is not optimized and therefore the headlamp is not used rationally. However, a larger leaf surface area is undesirable, as a result of mutual shading, much of the leaves in the lower tier fall off and the rest works inefficiently [11].

This indicator in soybeans can vary within wide enough limits depending on the genotype of the variety, environmental conditions of the region and agrotechnical measures of its cultivation [12-16].

In turn, these issues have not been addressed for the new mid-ripening Svyatogor soybean under irrigation in the south of Ukraine. Therefore, the purpose of our research was to determine the optimal parameters of photosynthetic activity of crops of soybean of the new medium-ripe variety of soybean Svyatogor for irrigation conditions of the Southern Steppe of Ukraine, depending on the density of plants and doses of nitrogen fertilizers.

Materials and methods of research. The studies were conducted during the 2016-2018 biennium at the research field of the Institute of Irrigated Agriculture of the NAAS in the breeding department located in the southern steppe region of Ukraine according to generally accepted field research methods and guidelines [17]. Two-factor experiment: factor $A$ - seeding rates $(300,400,500,600,700,800,900$ (thousand), 1 million pieces/ha); factor $B$ - doses of nitrogen fertilizers (without fertilizer, $N_{30}, N_{60}$ ). Repeat four times with 
placement of variants by the method of randomized split plots. The area of crops is $22 \mathrm{~m}^{2}$, accounting -18.5 $\mathrm{m}^{2}$. Agrotechnical research conditions are generally accepted for the southern region of Ukraine, except for the variants studied. Winter wheat was the precursor. Ammonium nitrate was introduced into the pre-sowing cultivation, according to the scheme of experience manual scattering.

The sowing was carried out with the SKS-6-10 seeder in a wide-row manner, with spacings of $45 \mathrm{~cm}$ on May 2, 2016, and the 6th in 2017, on April 26, in 2018. Soybean seeds on the day of sowing were treated with a preparation of nitrogen-fixing bacteria based on strain Bradyrhizobium japonicum 634 b; protection against pests was carried out by treatment with the drug Maxim XL $(1 \mathrm{l} / \mathrm{t})$. On soybean crops, soil moisture of $0-50 \mathrm{~cm}$ soil was maintained by irrigation not less than $70 \%$ HB. During the growing season in 2016 there were 7, in 2017 - 9, in 2018 - 8 irrigation sprinkler DDA-100 MA norm 400-500 $\mathrm{m}^{3} / \mathrm{ha}$.

Weed control was carried out by applying the Harness soil herbicide (2 l/ha) immediately after sowing with subsequent rolling, in June by treatment of crops with the insurance herbicide Picador (1 I/ha). The crop was harvested separately by the Sampo-130 harvester at full maturation of the seeds (humidity - 14-16\%).

The soil of the study areas is dark chestnut medium loam. The agrophysical properties of a meter layer of soil were characterized by the following parameters: density of the structure $-1,41 \mathrm{~g} / \mathrm{cm}^{3}$, total porosity $45 \%$, the lowest moisture capacity $-21.3 \%$, the wilting moisture $-9.1 \%$, the $\mathrm{pH}$ of the aqueous suspension 7,2 . The dark chestnut soils of the study area are well suited for producing high productivity soybean plants under the conditions of introducing the required number of mineral nutrients.

The limiting factor of technological support is insufficient rainfall during the growing season. The specificity of the zone is also sufficiently rigid actions of air drought during dry days. Years of research on the gradual evaporation gradation were: 2016 - to the average moisture deficit $(P=42.4 \%), 2017,2018-$ dry to the deficit of moisture ( $P=95.0 \%, P=98.0 \%$, respectively), with severe soil and air drought. SCC was in the range of $0.5-0.7$. Therefore, growing soybeans in the area of the southern steppe of Ukraine is possible only under irrigation.

Research results. The growth of the leaf apparatus was observed from the beginning of soybean budding to the onset of the seed filling phase. Leaf area had the highest values in the phase of seed filling on the background of $\mathrm{N}_{60}$ and $\mathrm{N}_{30}\left(51.34-52.42 \mathrm{~m}^{2} / \mathrm{ha}\right)$, the lowest - at the beginning of budding (18.12-18.93 $\mathrm{m}^{2} / \mathrm{ha}$ ). Regarding the density of plants on the plot, at the beginning of budding of the crop with each increase in seeding rate by 100 thousand/ha indicators of leaf area tended to increase. And on the plot with the density of standing plants 900 thousand units/ha reached the size of 19.13 thousand $\mathrm{m}^{2} /$ ha (Table 1 ).

1. Influence of elements of technology of soybean cultivation on the area of leaf surface of soybean plants in the process of its growth and development (2016-2018), thousand $\mathrm{m}^{2} / \mathrm{ha}^{2}$

\begin{tabular}{|c|c|c|c|c|}
\hline \multirow{2}{*}{$\begin{array}{c}\text { Mineral levels } \\
\text { power } \\
(\text { factor A) }\end{array}$} & \multirow{2}{*}{$\begin{array}{l}\text { Plant density, } \\
\text { thousand units/ha, } \\
\text { (factor B) }\end{array}$} & \multicolumn{3}{|c|}{ Phases of growth and development } \\
\hline & & $\begin{array}{l}\text { the beginning } \\
\text { of budding }\end{array}$ & flowering & poured seeds \\
\hline \multirow{3}{*}{ No fertilizer } & 300 & 12,03 & 18,50 & 23,05 \\
\hline & 600 & 15,09 & 21,88 & 26,19 \\
\hline & 900 & 16,64 & 24,94 & 32,01 \\
\hline \multirow{3}{*}{$\mathrm{N}_{30}$} & 300 & 16,02 & 22,25 & 47,38 \\
\hline & 600 & 18,12 & 26,01 & 52,42 \\
\hline & 900 & 17,93 & 25,65 & 50,56 \\
\hline \multirow{3}{*}{$\mathrm{N}_{60}$} & 300 & 17,01 & 22,21 & 46,70 \\
\hline & 600 & 18,93 & 23,57 & 51,34 \\
\hline & 900 & 19,13 & 22,74 & 49,92 \\
\hline
\end{tabular}

In the flowering phase, the area of leaf area was in the range of $18.50-26.01$ thousand $\mathrm{m}^{2} / \mathrm{ha}$.

Within the limits of the experiment of the largest sizes, the area of the photosynthetic surface reached the phase of seed filling. The introduction of mineral fertilizers significantly increased the size of the leaf area of soybean plants. With the introduction of $N_{30}$ and $N_{60}$, increasing the plant stand density from 300,000 to $600,000 /$ ha contributed to the intensive development of the soybean leaf apparatus. The maximum indices of leaf area of plants in the phase of seed filling at a density of 600 thousand plants/ha on the background of fertilizers by $50.0-51.0 \%$ dominated the unfertilized variant.

Therefore, the process of leaf growth prior to the onset of the seed filling phase in plants was observed as follows: in the phase of budding the area of the assimilation surface with increasing sowing density tended to increase; in the flowering phase, the sowing of 600,000 ha/ha resulted in a slight decrease in the size of the plant assimilation apparatus (by 0.36 and 0.83 thousand $\mathrm{m}^{2} / \mathrm{ha}$, compared to 300,000 ha/ha). The largest size of the leaf surface of soybean plants reached the phase of seed filling. 
Thickening of agrophytocenosis from 600 to 900 thousand plants/ha contributed to the reduction of the photosynthetic surface by 1.86-1.42 thousand $\mathrm{m}^{2} / \mathrm{ha}$. This was facilitated by increased intraspecific competition between plants: the growth of the assimilation apparatus is faster and due to the mutual shading, much of the leaves in the lower tier fall off and suppress. Plastic substances in such conditions of growth and development are used for the formation of stems and petioles [18].

The correlation-regression analysis of the experimental data yielded the equation $\left(y=0.0044 x^{2}-0.2843 x\right.$ $\left.+6,998 R^{2}=0.8332\right)$, which reflects the close dependence of soybean yield on the leaf area of the plants (fig. 1).

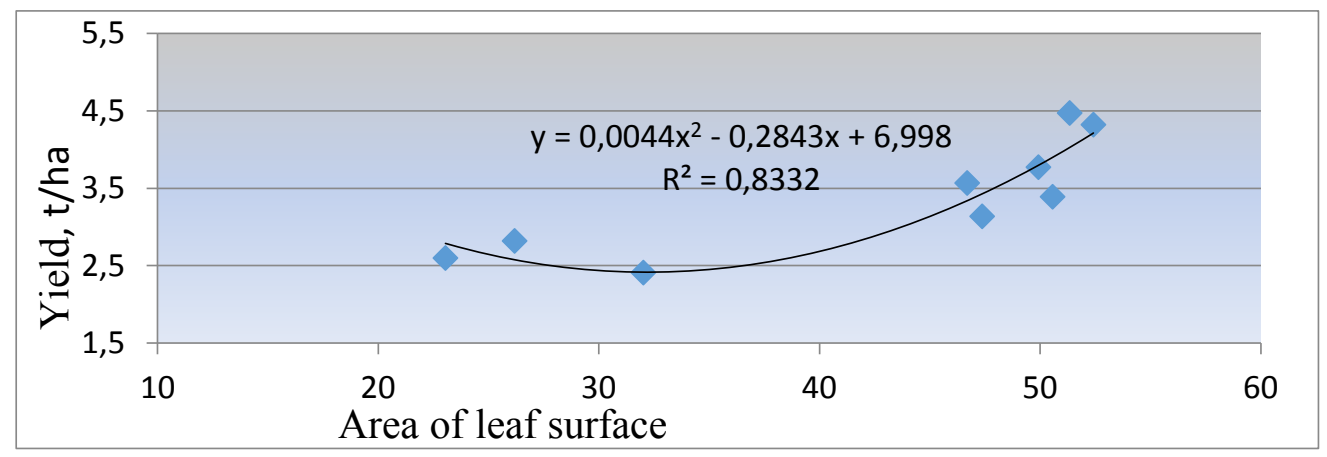

Fig. 1 The dependence of the productivity of seeds of soybean varieties Svyatogor on the area of leafy surface of plants

The best conditions for the growth of the leaf apparatus in the crops of soybean Svyatogor have developed at a plant stand density of 600 thousand/ha and the application of fertilizers in doses of $\mathrm{N}_{30}$ and $\mathrm{N}_{60}$. In the same areas, a high yield of soybean seeds of 4.32-4.47 t/ha was obtained (table 2).

2. Seed productivity of medium-ripe soybean seeds of Svyatogor depending on the level of nitrogen nutrition and plant density (average for 2016-2018), thousand pieces/ha

\begin{tabular}{|c|c|c|c|c|c|c|c|c|c|}
\hline \multirow{2}{*}{$\begin{array}{c}\text { Mineral levels } \\
\text { power } \\
\text { (factor A) }\end{array}$} & \multicolumn{8}{|c|}{ Plant density, thousand units/ha, factor B. } & \multirow{2}{*}{$\begin{array}{l}\text { The } \\
\text { average of } \\
\text { factor } A \text {, } \\
\text { t/ha }\end{array}$} \\
\hline & 300 & 400 & 500 & 600 & 700 & $00^{8}$ & $00^{9}$ & $\begin{array}{l}100 \\
0\end{array}$ & \\
\hline No fertilizer & $\begin{array}{l}2,5 \\
7\end{array}$ & $\begin{array}{l}2,5 \\
4\end{array}$ & $\begin{array}{l}2,9 \\
1\end{array}$ & $\begin{array}{l}2,7 \\
9\end{array}$ & $3^{2,6}$ & $\begin{array}{c}2, \\
58\end{array}$ & ${ }^{2}$ & $\begin{array}{l}2,4 \\
1\end{array}$ & 2,62 \\
\hline $\mathrm{N}_{30}$ & $\begin{array}{l}3,1 \\
4\end{array}$ & $\begin{array}{l}3,1 \\
6\end{array}$ & $\begin{array}{l}3,2 \\
9^{3,2}\end{array}$ & $\begin{array}{l}4,3 \\
2\end{array}$ & $\begin{array}{l}3,7 \\
2\end{array}$ & $\begin{array}{r}3 \\
21\end{array}$ & $\begin{array}{c}3 \\
39\end{array}$ & 3,33 & 3,46 \\
\hline $\mathrm{N}_{60}$ & $\begin{array}{l}3,5 \\
7\end{array}$ & $\begin{array}{l}3,5 \\
8\end{array}$ & $\begin{array}{l}4,0 \\
7\end{array}$ & $\begin{array}{l}4,4 \\
7\end{array}$ & $\begin{array}{l}4,2 \\
5\end{array}$ & $\begin{array}{r}3, \\
99\end{array}$ & $\begin{array}{r}3 \\
77\end{array}$ & $\begin{array}{l}3,6 \\
9^{3}\end{array}$ & 3,92 \\
\hline $\begin{array}{l}\text { The average } \\
\text { factor } B \\
\text { t/ha }\end{array}$ & $\begin{array}{l}3,1 \\
0\end{array}$ & $\begin{array}{l}3,0 \\
7\end{array}$ & $2^{3,4}$ & $\begin{array}{l}3,8 \\
7\end{array}$ & $\begin{array}{l}3,5 \\
4\end{array}$ & 3 & $\begin{array}{r}3 \\
19\end{array}$ & $\begin{array}{l}3,1 \\
5\end{array}$ & \\
\hline & me & & & 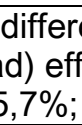 & & & & & \\
\hline
\end{tabular}

The analysis of the obtained results revealed that from the flowering phase to the bean filling, there was an intense increase of the leaf surface of soybeans, in connection with which the photosynthetic potential of crops during this interphase period increased significantly and reached its maximum - 1,23-1,38 million $\mathrm{m}^{2} /$ ha (table 3).

3. Photosynthetic potential of sowing of medium-ripe Svyatogor soybean depending on different doses of nitrogen fertilizers and sowing density (average for 2016-2018), m/n.m $\mathrm{m}^{2} \mathrm{~d} / \mathrm{ha}$

\begin{tabular}{|c|c|c|c|c|c|}
\hline \multirow[b]{2}{*}{$\begin{array}{c}\text { Mineral levels } \\
\text { power } \\
\text { (factor A) }\end{array}$} & \multirow{2}{*}{$\begin{array}{l}\text { Plant } \\
\text { density, } \\
\text { thousand } \\
\text { units/ha, } \\
\text { (factor B) }\end{array}$} & \multicolumn{3}{|c|}{ Phases of growth and development } & \multirow{2}{*}{$\begin{array}{l}\text { For all the } \\
\text { growing } \\
\text { season }\end{array}$} \\
\hline & & $\begin{array}{c}\text { the } \\
\text { beginning of } \\
\text { budding }\end{array}$ & flowering & $\begin{array}{l}\text { poured } \\
\text { seeds }\end{array}$ & \\
\hline \multirow[t]{2}{*}{ No fertilizer } & 300 & 0,21 & 0,21 & 0,63 & 1,72 \\
\hline & 600 & 0,25 & 0,25 & 0,76 & 2,09 \\
\hline
\end{tabular}




\begin{tabular}{|c|c|c|c|c|c|}
\hline & 900 & 0,28 & 0,28 & 0,84 & 2,34 \\
\hline \multirow{3}{*}{$N_{30}$} & 300 & 0,27 & 0,29 & 1,20 & 2,96 \\
\cline { 2 - 6 } & 600 & 0,31 & 0,34 & 1,38 & 3,45 \\
\cline { 2 - 6 } & 900 & 0,31 & 0,34 & 1,32 & 3,33 \\
\hline \multirow{3}{*}{$N_{60}$} & 300 & 0,29 & 0,30 & 1,18 & 2,97 \\
\cline { 2 - 6 } & 600 & 0,33 & 0,33 & 1,23 & 3,19 \\
\cline { 2 - 6 } & 900 & 0,33 & 0,31 & 1,16 & 3,05 \\
\hline
\end{tabular}

It was formed with varying intensity throughout the growing season and varied depending on different doses of fertilizers and plant densities. Increase in sowing density from 600 to 800 thousandth contributed to the improvement of photosynthetic potential, and already 900 thousand plants/ha led to a decrease in this indicator.

Correlation-regression analysis of the obtained indicators allowed us to obtain the equation of the dependence of seed yield on the value of photosynthetic potential of the variety of soybean Svyatogor: $y=$ $0.5974 \mathrm{x}^{2}+4.4396 \mathrm{R}^{2}=0.7141$, which confirms the close dependence between these indicators, and shows that the regulation The photosynthetic potential of plants can significantly influence the formation of soybean yields.

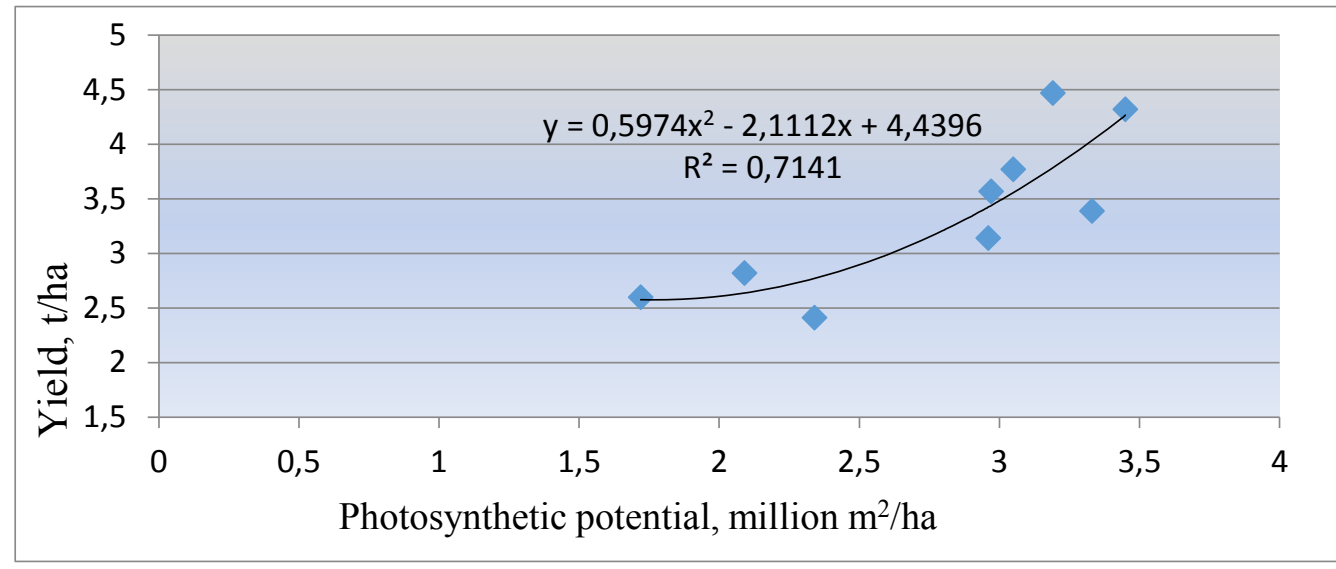

Fig. 2 The dependence of the seed yield of the soybean variety Svyatogor on the value of photosynthetic potential

\section{Conclusions}

For the first time in the conditions of Southern Ukraine peculiarities of formation of photosynthetic activity of crops of middle-ripening variety of soybean Svyatogor have been established, depending on the density of standing plants, doses of nitrogen fertilizer, providing yields at the level of 4.32-4.47 t/ha.

It is found that the maximum leaf area area in the phase of seed filling was 52.42 thousand $\mathrm{m}^{2} / \mathrm{ha}$ for plant densities of 600 thousand units/ha, the level of application of nitrogen fertilizer, which implies a dose of $N_{30}$.

The best indices of photosynthetic potential for the whole period of vegetation - 3.45-3.19 million $\mathrm{m}^{2} / \mathrm{ha}$ were formed in the areas where the plant density was 600 thousand units/ha on the background of $N_{30}$ and $N_{60}$, respectively.

\section{References}

1. Motruk, V. N. (1999). Roslynnytstvo [Crop Production]. Kyiv: Harvest. [In Ukrainian].

2. Zinchenko, O. I., Salatenko, N. V., \& Bilonozhko, M. A. (2001). Roslynnytstvo [Crop Production]. Kyiv: Agricultural Education. [In Ukrainian].

3. Babich, A. O. (1998). Soia dlia zdorovia i zhyttia na planeti Zemlia [Soybean for Health and Life on Planet Earth]. A monograph. Kyiv: Agrarian Science. [In Ukrainian].

4. Vozhehova, R. A., \& Melnyk, M. A. (2014). Osoblyvosti nakopychennia syroi masy ta sukhoi rechovyny, fotosyntetychna diialnist soi pry vyroshchuvanni v umovakh Pivdnia Ukrainy [Peculiarities of raw mass and dry matter accumulation, photosynthetic activity of soybean during cultivation in the South of Ukraine]. Bulletin of Agrarian Science of the Black Sea Region, 4, 114-121. [In Ukrainian].

5. Gritsayko, Z. M, Gritsayenko, A. O., \& Karpenko, V. P. (2003). Metody biolohichnykh ta ahrokhimichnykh doslidzhen roslyn ta gruntiv [Methods of biological and agrochemical studies of plants and soils]. Kyiv: Nichlava. [In Ukrainian]. 
6. Wells, R. (1991). Soyabean growth response to plant density: Relationships among canopy photosynthesis, leaf area and light interception. Crop Science, 31, 755-761. doi: 10.2135/cropsci1991 $.0011183 \times 003100030044 x$.

7. Caulfield, F., \& Bunce, J. (1988). Comparative responses of photosynthesis to growth temperature in soybean (Glycine max (L.) Merr.) cultivars. Canad. J. Plant Sc., 68(2), 419-425. doi: 10.4141/ cjps88-053.

8. Bone, S. (1978). Reduces tillage systems for soybean production. Soybean news, 28(2), 1-2.

9. Krugova, O. D., Mandrovskaya, N. M., \& Bublik, L. I. (2008). Vitalyst stymuliuie posivy soi. Vplyv mikrodobryva na symbiotychnu systemu kultury [Vitalist stimulates soybean crops. The influence of fertilizers on the symbiotic culture system]. Quarantine and plant protection, 7, 19-20. [In Ukrainian].

10. Vozhegova, R. A., Borovik, V. O., Marchenko, T. Yu., \& Rubtsov, D. K. (2018). Nasinnieva produktyvnist serednostyhloho sortu soi "Sviatohor" zalezhno vid normy vysivu ta doz azotnykh dobryv $\mathrm{v}$ umovakh zroshennia pivdnia Ukrainy [Seed productivity of medium-ripening variety of soybean "Svyatogor" depending on the rate of seeding and doses of nitrogen fertilizers in irrigation conditions of the south of Ukraine]. Irrigated agriculture, 70, 55-59. [In Ukrainian].

11. Belinsky, Y. V. (2013). Produktyvnist soi zalezhno vid sposobiv sivby v umovakh skhidnoi chastyny Livoberezhnoho Lisostepu Ukrainy [Soybean productivity depending on sowing methods in the conditions of the eastern part of the Left Bank Forest Steppe of Ukraine]. Bulletin of the Center for Scientific Support of the APA of Kharkiv region, 14, 21-29. [In Ukrainian].

12. Volynets, I. G. (2008). Pozhyvnyi rezhym chornozemu opidzolenoho pry vyroshchuvanni soi za riznykh umov mineralnoho zhyvlennia [Nutrient regime of podzolic chernozem in soybean cultivation under different mineral nutrition conditions]. Bulletin of Agrarian Science of the Black Sea. Mykolaiv, 3(2), 38-44.

13. Klubuk, V. V. (2018). Zviazok strukturnykh elementiv introdukovanykh zrazkiv soi (GLYCINE MAX. (L.) MERR.) z produktyvnistiu nasinnia $v$ umovakh zroshennia pivdnia Ukrainy [Relationship of structural elements of introduced soybean samples (GLYCINE MAX. (L.) MERR.) With seed productivity in irrigation conditions of southern Ukraine]. Genetic resources of plants, 22, 11-18. [In Ukrainian].

14. Bakhmat, O. M. (2012). Modeliuvannia adaptyvnoi tekhnolohii vyroshchuvannia soi. [Modeling of adaptive soybean cultivation technology]. A monograph. Kamianets-Podilskyi: Publisher Zvoleyko D. G. [In Ukrainian].

15. Wildflush, I. R. (2011). Effektyvnost prymenenyia mykroudobrenyi y rehuliatorov rosta pry vozdeluvanyy selskokhoziaistvennykh kultur [Efficiency of the use of micronutrient fertilizers and growth regulators in the cultivation of crops]. Minsk: Belarusian science. [In Russian].

16. Pisarenko, V. A., Kokovikhin, S. V., Suzdal, O. S., \& Kazanok, O. O. (2008). Planuvannia rezhymu zroshennia soi za pokaznykamy serednodobovoho vyparovuvannia [Planuvannya to the regime of malignancy according to the indicators of mid-year viparovuvannya]. Irrigated agriculture, 49, 6-10. [In Ukrainian].

17. Vozhegova, R. A., Lavrinenko, Yu. O., \& Malyarchuk, M. P. (2014). Metodyka polovykh $i$ laboratornykh doslidzhen na zroshuvanykh zemliakh [Methods of polishing and laboratory research on zroshuvani lands]. Kherson: Grin D. S. [In Ukrainian].

18. Zabolotny, G. M., \& Spolitak, N. M. (2009). Dynamika vysoty roslyn soi zalezhno vid modelei tekhnolohii vyroshchuvannia [Dynamics of vertical rosin fallow in the form of models of technological viroschuvannya]. Collection of scientific works of Vinnytsia State Agrarian University. (Vol. 38, pp. 32-38). Vinnitsya. [In Ukrainian]. 